\title{
The use of factor analysis and acid base accounting to probe the speciation of toxic metals in gold mine waste
}

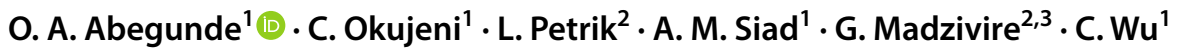

Received: 2 July 2019 / Accepted: 25 February 2020 / Published online: 17 March 2020

c) Springer-Verlag GmbH Germany, part of Springer Nature 2020

\begin{abstract}
The generation of acidic drainage has become pervasive over the years and toxic elements are released due to exposure to oxidising agents, unforeseen circumstances, and human interactions. Uncontrolled acidic mine drainage release can result in substantial ecological disruption in sensitive and productive receiving waters. This study probes the element mobility of gold tailings with regard to various zones identified, based on possible phenomena such as the natural water medium, or acidic and alkaline media using sequential extraction and multivariate analyses. Factor analysis results, coupled with mineralogy, were corroborated with acid generation potential to identify various relationships that exist and establish the efficacy of the research towards predicting acid mine drainage generation potential. The statistical analysis was able to establish that $\mathrm{pH}$ or acidity, Fe ions, $\mathrm{Ca}^{2+}$ and $\mathrm{Mg}^{2+}$ played a major role in the released metals. Out of the four factors ( $80.8 \%$ accounted for) identified in factor analysis results for water fraction (WF), Fe contributed to three factors which showed the presence of $\mathrm{Fe}$ ions (assuming $\mathrm{Fe}^{2+}$ and $\mathrm{Fe}^{3+}$ ) responsible for the increased acidity of the tailings. The net acid producing potential and cumulative net acid producing potential showed that overall; the tailings would generate acidity due to the high presence of leachable sulphides. The trends observed in the carbonate phase indicated that despite the posit of acidity, the tailings contain a considerable amount of neutralising agent to serve as a buffer.
\end{abstract}

Keywords Tailings $\cdot$ Acid generation potential $\cdot$ Assessment $\cdot$ Statistics $\cdot$ Contamination $\cdot$ Prediction $\cdot$ Sequential extraction · Drainage

O. A. Abegunde: Iphakade No 223.

Electronic supplementary material The online version of this article (https://doi.org/10.1007/s12665-020-8887-7) contains supplementary material, which is available to authorized users.

O. A. Abegunde

3207599@myuwc.ac.za

1 Department of Earth Sciences, University of the Western Cape, Bellville, Cape Town, South Africa

2 Department of Chemical Science, University of the Western Cape, Bellville, Cape Town, South Africa

3 Council for Geoscience, Mine Water and Solid Residues Management, Sustainable Resources and Environment Competency, 280 Pretoria Street, Silverton, Pretoria 0084, South Africa

\section{Introduction}

New mines or active old mines are obliged to provide proof that waste materials produced in the course of processing are stockpiled in a way that will inhibit or alleviate the release of acidic drainage, minimise the transport of elements that contaminate runoff, and prevent drainage and seepage, including downstream channels during mining and in future when mines are closed down (Lawrence and Scheske 1997). Despite this, the generation of acidic drainage has become pervasive over the years, and many studies have been done to confirm this.

However, the process that determines the possibility of toxic elements being sequestered or released in mine wastes is based on mineral-water interactions, to comprehend the chemical reaction complexities, fresh and weathered material needed to be characterised, in depth, for the existing reactive minerals (Jamieson et al. 2015). Uncontrolled acidic mine drainage released could result in substantial ecological disruption in sensitive and productive receiving waters. 
When sulphide minerals in the waste rock and tailings environment are borne to the atmosphere (water and oxygen), they tend to swiftly oxidise. This process is frequently catalysed by bacteria. Pyrite and pyrrhotite, commonly found as gangue minerals in several ore deposits, are mostly responsible for the generation of low- $\mathrm{pH}$ (acidic) waters. As soon as this acidic environment is established, other sulphides, silicates, oxides, and carbonate minerals are dissolved and discharged. Also, depending on the nature of the ore deposit, metals such as $\mathrm{Zn}, \mathrm{Cu}, \mathrm{Ni}, \mathrm{Pb}, \mathrm{Al}, \mathrm{Cd}, \mathrm{Hg}$, Co, $\mathrm{Mn}$, and $\mathrm{U}$, as well as metalloids, including $\mathrm{Sb}$ and $\mathrm{As}$ are leached (Jamieson et al. 2015).

Several methods have been used to understand such complexities, including acid base accounting (Skousen et al. 2002; Price et al. 1997; Paktunc 1999; Parbhakar-Fox and Lottermoser 2015; Bouzahzah et al. 2014), sequential and/ or selective extraction procedures (Favas et al. 2011; Martin et al. 1987; Yong et al. 1993; Gleyzes et al. 2002; Eze et al. 2013), column leaching techniques (Tutu et al. 2008), and chemometric evaluation (Abollino et al. 2011)

Several studies predicted elemental mobility in gold tailings coupled with factor analysis to measure species leachability and behaviour of tailings dump material over long periods of time (Cukrowska et al. 2004; Tutu et al. 2008). However, mineral forms of elements of interest and their predominant geochemical conditions play a major role in environmental mobility (e.g. solubility and sorption-desorption) and the risk it poses to human and environmental health. Factor analysis has not been as extensively used as principal component analysis in probing single and sequential extraction results (Abollino et al. 2011).

Hence, the use of multivariate statistics to probe environmental analytical data sets has been successfully applied. Most studies focused on certain parts of tailings dams. However, the whole (not only its bottom, sides, or surface) profiling of the tailings dam during sampling collection preferably would have been of great significance for constant monitoring and elemental mobility valuation (Tutu et al. 2008).

This study probes the element mobility of gold tailings with regard to various zones identified (Abegunde et al. 2016), based on possible phenomena such as the natural water medium or acidic and alkaline media using sequential extraction and multivariate analysis. In addition, the study evaluates the state of tailings, environmental conditions for the release of element, the control of mineralogy within tailings, and the pattern of elements released under different environmental condition. Factor analysis and mineralogical evaluation were used to extract more information from a three-step modified sequential extraction procedure (SEP) method. This approach aids better understanding of the elemental speciation or mobility from Mogale tailing dam in Randfontein area, Witwatersrand Basin, South Africa. The use of acidic potential determination of the tailings and its bulk chemistry in predicting the acid mine drainage (AMD) loads discharged into the environment over time was done. Furthermore, factor analysis results were corroborated with acid generation potential to identify various relationships that exist and establish the efficacy of the research towards predicting AMD generation potential.

\section{Materials and methods}

\section{Study area}

The study area is located along the Randfontein and Krugersdorp (R28) road in the Gauteng province (see Fig. 1).

The tailing dam was constructed around 1952 and it is about $70 \mathrm{~m}$ deep from the top to the ground surface. This tailing dam is partially vegetated (some parts are vegetated and others non-vegetated) and in some exposed parts, some parts of the tailings dam have been exposed

The climatic condition of this area is well known. It has a similar condition to Johannesburg, since it is situated in its northwest. The annual rainfall is about $750 \mathrm{~mm}$ and is strongly seasonal, while potential evaporation is about $1600 \mathrm{~mm} /$ annum. Most rain falls during the summer, between the October and February period. Thunderstorms of short duration account for most of the rainfall. Temperature averages about $20{ }^{\circ} \mathrm{C}$ during the summer months and about $15^{\circ} \mathrm{C}$ in winter (Naicker et al. 2003).

The study area is located within the lower unit of the Witwatersrand Supergroup called the West Rand Group. The West Rand Group is divided into hospital hill series, the government reef series, and the Jeppesstown series, and all in ascending order and each division corresponding to shales and quartzite groups (Mccarthy and Rubisge 2005; Viljoen and Reimold 2002). According to Schneiderhan (2008), 1600 m-thick lavas of the Ventersdorp supergroup, which were deposited between 2.714 and $2.665 \mathrm{Ga}$, overlie the Witwatersrand supergroup. Below the Ventersdorp supergroup (consisting mostly a sequence of igneous rock) lie a layer of sedimentary rock known as the (gold-bearing layer) Ventersdorp contact reef. This gold-bearing layer consists of the sediments deposited as a result of partial erosion of the Witwatersrand supergroup discordantly.

\section{Field sampling and sample preparation}

Five holes were drilled by an auger, locally termed as 'sanddrill', through the tailing dam to a depth of $10 \mathrm{~m}$, and samples were taken at every $1 \mathrm{~m}$. The drill cores were logged for changes in colour, texture, mineralogy, and additional samples collected where necessary (Abegunde et al. 2016). Each hole was drilled through the oxidised zone into the primary 
Fig. 1 Map of the study area showing various goldfields in Witwatersrand basin

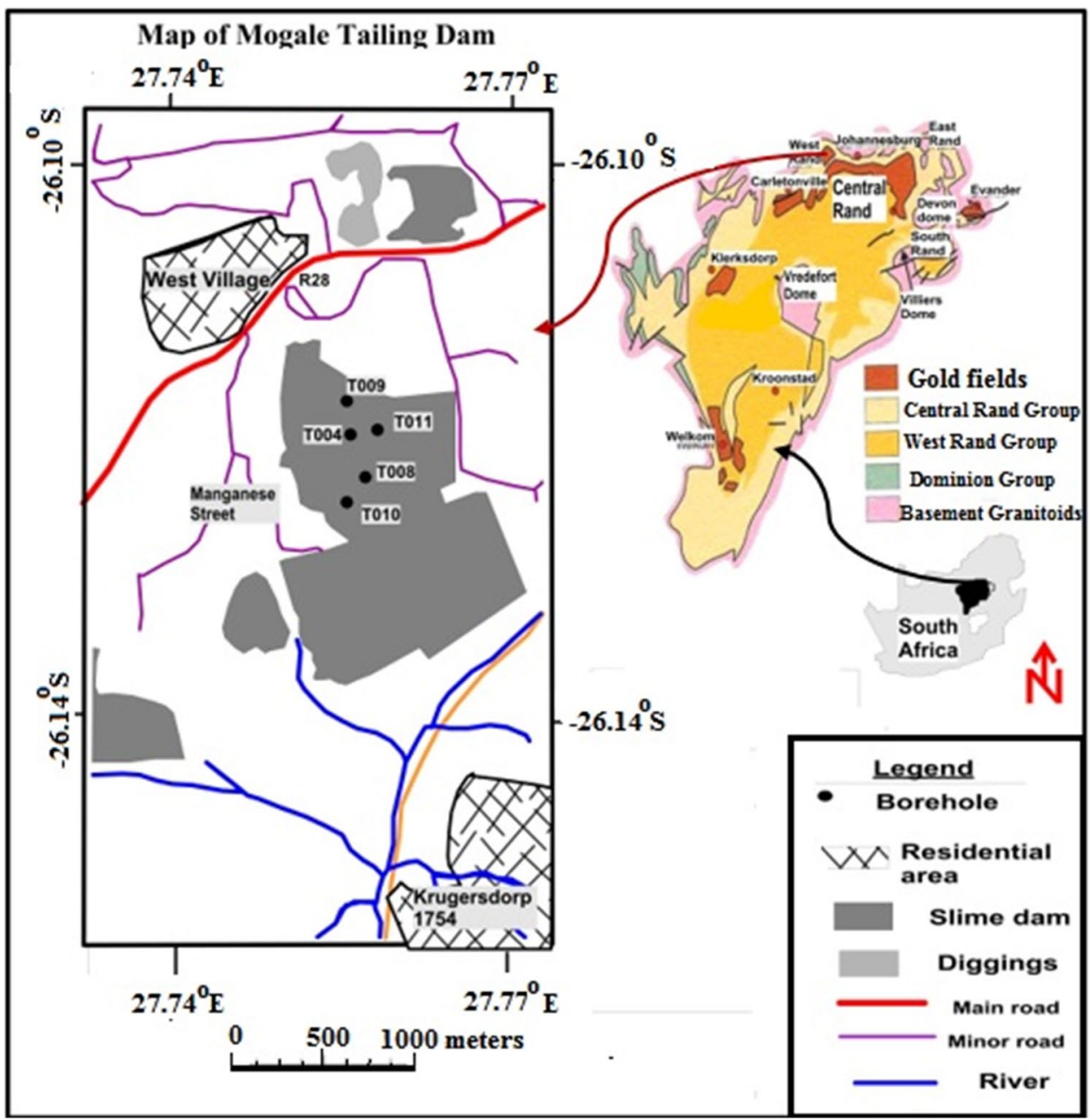

grey tailings before termination. Although the Mogale tailing dump is up to $75 \mathrm{~m}$ high, the sampling was restricted to the first $10 \mathrm{~m}$. According to Nengovhela et al. (2007) and Bezuidenhout and Rousseau (2006), AMD discharge is most distinct within the upper $5 \mathrm{~m}$ (unsaturated zone) in the West Rand. Fifty-six tailing samples were collected, wrapped separately in plastic tubing, and then packed in boxes. All samples were dried at $40{ }^{\circ} \mathrm{C}$ for $16 \mathrm{~h}$ (since temperature does not exceed the boiling points of the most volatile targeted elements) (EPA 2015), then homogenised and a portion pulverised by Dickie and Stockler milling machine.

\section{Analytical procedures}

The mineral phase and composition of the sample were analysed using Zeiss Gemini Auriga high-resolution scanning electron micro-analyser (HR-SEM), furnished with a CDU-lead detector at $25 \mathrm{kV}$ and a tungsten filament. The current and illumination were fixed at $5 \mathrm{kV}$ and $0.1 \mathrm{mrad}$, whereas the magnification, working distance, and resolution were captured on each sample micrograph. The qualitative elemental composition for each analysed sample focus spot was analysed by energy-dispersive spectroscopy (EDS).

Fifty-one samples were sent to ACME Analytical Laboratories Ltd (Vancouver) for multi-elemental analysis. All major oxides were analysed by X-ray fluorescence (XRF), and trace elements by inductively coupled plasma-mass spectrometry (ICP-MS) techniques following a lithium metaborate fusion and nitric acid digestion. Standards used were STD GS311-1, STD GS910-4, STD OREAS45EA, STD OREAS72A, STD SO-18, STD SY-4(D), STD DS9, and STD OREAS45EA.

The total sulphur and carbon were also determined by Leco analysis, while the estimated sample acid production was determined by paste $\mathrm{pH}$ method along with electrical conductivity (EC).

About 34 samples, as identified by Abegunde et al. (2016), were selected according to various zones and subjected to a three-step modified sequential extraction (Eze et al. 2013). Multi-elemental analysis of each sequential leach phase was analysed by inductively coupled plasmaoptical emission spectrometry (ICP-OES) techniques. 
Following the three-step sequential extraction, the results generated in each phase were analysed using multivariate statistics (such as cluster analysis, discriminant function analysis, and factor analysis). The factor analysis was used to probe the relationship and source pattern within each phase to help understand the mobility of elements.

Water leach (step 1) The water-leach phase targeted the most labile species present in the wastes. Hence, the most labile and bio-available elements leached represent the effect of rainwater on the waste in the environment. $3 \mathrm{~g}$ of selected gold tailings sample was measured into a $50 \mathrm{~mL}$ centrifuge tube and $45 \mathrm{~mL}$ of ultrapure water $\left(\mathrm{H}_{2} \mathrm{O}\right)$ was added at $25^{\circ} \mathrm{C}$. The samples were then placed in a mechanical shaker for $2 \mathrm{~h}$. The process was repeated to produce duplicate samples, and the solution was made to stand for $1 \mathrm{~h}$. Afterwards, each sample was placed in a centrifuge at $5000 \mathrm{rpm}$ for $20 \mathrm{~min}$ and the supernatant filtered through a $42 \mu \mathrm{m}$ filter paper. The remaining solid portion was carefully decanted into a $100 \mathrm{~mL}$ plastic clear bottle to reduce weight loss. The filtered supernatant solution obtained was prepared for analysis of major and trace species with ICP-MS by using a dilution factor of 10 . The solid residue remaining after the extraction of each sample was quantitatively recovered and kept in a refrigerated condition for the next extraction method.

Ammonium acetate leach (Extraction at pH 5) Ammonium acetate leach depicted the exchangeable metals and/or those soluble in slightly acidic conditions. $45 \mathrm{~mL}$ of $1 \mathrm{M}$ ammonium acetate buffer solution at $\mathrm{pH} 5$ was poured into the solid remains recovered from step 1 at $25^{\circ} \mathrm{C}$. The centrifuging and recovery procedure given in Step 1 was followed again.

Hydroxylamine hydrochloride leach Hydroxylamine hydrochloride leach identified metals associated with $\mathrm{Fe}$ and $\mathrm{Mn}$ oxides that can be leached out if conditions alter from oxic to anoxic state (Favas et al. 2011; Eze et al. 2013). $45 \mathrm{~mL}$ of hydroxylamine hydrochloride $(0.25 \mathrm{M})$ in nitric acid $(0.025 \mathrm{M})$ solution was added to each sample of the solid residue recovered from step 3 . The solution was shaken for $1 \mathrm{~h}$ at room temperature. The same process given in Step 1 was followed.

Prior to the sequential extraction, a pre-analysis was performed to determine the most suitable sample matrix and leaching agent used, in terms of weight of samples, run time for leaching, the concentration of leaching agents, as well as the weight of tailings sample required (Fig. 2). Triplicate samples generated were analysed to ascertain which was the best method of combination. Lower concentration of hydroxylamine and $\mathrm{pH} 5$ buffer solution of ammonium acetate released more of our targeted elements. Based on concentration, lower conc of hydroxylamine tends to release more $\mathrm{Cu}, \mathrm{Ni}, \mathrm{Zn}$ while ammonium acetate at $\mathrm{pH} 5$ buffer release more elements.

Precision and accuracy of all data were determined using pulp duplicates, triplicates (SEP) and reference materials

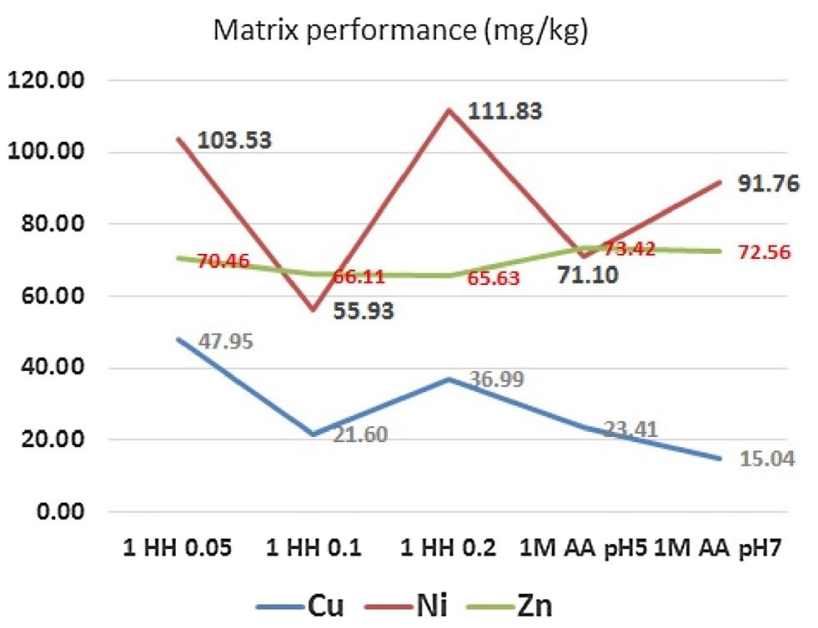

Fig. 2 Matrix performance for some selected trace elements

(Abzalov 2008; Piercey 2014). The precision error for all major elements and LOI (excluding $\mathrm{MgO}, \mathrm{K}_{2} \mathrm{O}$, and $\mathrm{TiO}_{2}$ ) is less than $5 \%$. The precision error for trace elements is less than $10 \%$. The accuracy for all major elements falls within $0.34-4.26 \%$ and for trace elements between 0.18 and $6.25 \%$. Percentage relative difference is given by $(\% \mathrm{RD})=100 \times\left(M_{e}-\mathrm{STD} e\right) / \mathrm{STD} e$, where $M_{e}$ is the mean value of element $e$ in the standard over a number of replicate analyses results of the reference or standard material. $\mathrm{STD} e$ is the certified or known value of element $e$ for the standard or reference materials used. The $\% \mathrm{RD}$ values fall below $\pm 7 \%$ which shows that the data quality is very good.

\section{Statistical analyses}

Factor analysis was carried out to probe, identify, and predict the speciation based on relationships. Complete statistical analysis of sequential extraction procedure results (each phase analysed differently) was performed by using IBM SPSS $20^{\circledR}$ software. As part of the analytical processes, factor analysis emphasised the main factors that defined the compositional variation patterns of major element and heavy metals present within each sequential extraction phase. The principal component method was used to establish the eigenvalue > 1 (Loska and Wiechuła 2003; Slavkovic et al. 2004; Alkarkhi et al. 2009; Mil-Homens et al. 2013). A varimax rotation method that suppresses small coefficient greater than 0.3 was used.

\section{Acid base accounting (ABA)}

Acid base accounting (ABA) was used to infer the acid potential of the tailings sample, based on the assumption that the values of the total $\% \mathrm{~S}$ in samples can be used to 
calculate the acid base accounting parameters for the tailings (Price 2009; Parbhakar-Fox and Lottermoser 2015; Skousen 2017). To avoid significant overestimation, the sulphide-sulphur test was done. For the measurement of the sulphidesulphur, $1 \mathrm{~g}$ of tailing samples was dissolved in $45 \mathrm{ml}$ of $0.2 \mathrm{M}$ ammonium oxalate, at $\mathrm{pH} 3.0$, at a temperature of $80^{\circ} \mathrm{C}$ and leached for $2 \mathrm{~h}$.

More so, static test (form of ABA) was done to assess and quantify the acid-generating potential (Gautama and Kusuma 2008; Oh et al. 2017) of mine wastes. The total \%S is assumed to be a conventional estimate of the sulphide content of the sample synonymous to the total amount of sulphur present in the tailings that can be oxidised, while total sulphide-sulphur is the potential sulphides that can generate acidic leachates (Parbhakar-Fox and Lottermoser 2015). The maximum potential acidity was calculated, assuming that $100 \%$ of the sulphur present is available to produce acid. The reaction given below will be considered. It is important that the role sulphur plays in the speciation of the tailings is probed, including its relationships to various phases and their elemental mobility.

$\mathrm{FeS}_{2}+15 / 4 \mathrm{O}_{2} \rightarrow \mathrm{Fe}(\mathrm{OH})_{3}+2 \mathrm{H}_{2} \mathrm{SO}_{4}$.

From the balanced stoichiometric reaction above, the mass of $1 \%$ pyrite translates to $30.6 \mathrm{~kg}$ of $\mathrm{H}_{2} \mathrm{SO}_{4}$ per tonne of materials $\left(\mathrm{kg} \mathrm{H}_{2} \mathrm{SO}_{4} / \mathrm{t}\right)$. From this, the maximum potential acidity is calculated as the product of the weight of the total sulphur (in \%) multiplied by 30.6 .

In addition, since calcium carbonate $\left(\mathrm{CaCO}_{3}\right)$ reacts to neutralise $\mathrm{H}_{2} \mathrm{SO}_{4}$ generated on a 2:1 stoichiometric ratio, the comparative acid-neutralising capacity is a function of the amount of $\mathrm{CaO}$ content present, which is expressed in the weight of $\mathrm{H}_{2} \mathrm{SO}_{4}$.

$2 \mathrm{CaCO}_{3}+2 \mathrm{H}_{2} \mathrm{SO}_{4} \rightarrow 2 \mathrm{CaSO}_{4}+2 \mathrm{H}_{2} \mathrm{O}+2 \mathrm{CO}_{2}$

From Eq. 2, to express \% $\mathrm{CaO}$ with respect to $\% \mathrm{~S}$, a conversion factor is required. This is because the molecular weight of $\mathrm{CaO}$ is 56 , which is greater than $\mathrm{S}$ (32). In this study, 0.57 is used as the conversion factor. From the \% $\mathrm{CaO}$, the neutralisation potential (NP) of the tailings can be calculated by assuming that, $\% \mathrm{CaO}$ is responsible for the neutralisation process in the tailings. Then, this is calculated as $\% \mathrm{CaO}$ multiplied by $30.6 \mathrm{~kg}$ of $\mathrm{H}_{2} \mathrm{SO}_{4}$ per tonne of materials and the conversion factor.

Another method used in this study is the calculation of the $\mathrm{MgO}$ NP. This approach is made possible by considering the substantiality of the $\mathrm{MgO}$. This demonstrates its involvement in the neutralisation process by having similar characteristics to undergo the same reaction as $\mathrm{CaO}$. Therefore, the summation of all the materials that are responsible for neutralisation is calculated as follows:
$(\% \mathrm{CaO} \times 30.6 \times$ conversion factor for $\mathrm{CaO}(0.57)$

$+\% \mathrm{MgO} \times 30.6 \times$ conversion factor for $\mathrm{MgO}(0.8))$

$=$ cumulative neutralisation potential $(\mathrm{CNP})$.

\section{Results and discussion}

\section{Data summary}

Table 1 lists the selected major and trace elements for the whole composite dataset and SEP phase analysis of samples from the Mogale tailings dam. An appraisal of Table 1 shows that $\mathrm{SiO}_{2}$ (84.24\%), $\mathrm{Al}_{2} \mathrm{O}_{3}(6.25 \%), \mathrm{Fe}_{2} \mathrm{O}_{3}(2.64 \%)$ and LOI (3.28\%) defined about $97.05 \%$ of the whole composition of the samples, while concentrations of $\mathrm{U}, \mathrm{Au}$, $\mathrm{Ni}, \mathrm{As}, \mathrm{Cu}$, and $\mathrm{Zn}$ have maximum values of $655.5 \mathrm{mg} / \mathrm{kg}$, $1.4177 \mathrm{mg} / \mathrm{kg}, 274.1 \mathrm{mg} / \mathrm{kg}, 471.4 \mathrm{mg} / \mathrm{kg}, 308.8 \mathrm{mg} / \mathrm{kg}$, and $817 \mathrm{mg} / \mathrm{kg}$, respectively (Abegunde et al. 2016). The average arsenic contents are also well above $100 \mathrm{mg} / \mathrm{kg}$.

Based on the selected elements, Table 1 compares the whole sample data with their corresponding leached values for each SEP leached phase. For the major elements, their equivalent values in \% oxide for the whole sample were converted to $\mathrm{mg} / \mathrm{kg}$ to allow proper comparison. Except for $\mathrm{Ca}, \mathrm{Mn}, \mathrm{Cu}, \mathrm{Zn}, \mathrm{Co}$ and $\mathrm{Ni}$, all other elements' maximum concentration is lower than the minimum concentration of their corresponding whole composite value. The percentage leached for each selected element was calculated based on their average values.

However, subject to the mean, $\mathrm{Ca}, \mathrm{Mg}, \mathrm{Fe}, \mathrm{K}$, and $\mathrm{Na}$ are generally the prevalent concentration (see Table 1) of the bulk composition of the samples in each sequential extraction phase. Except for $\mathrm{Zn}$ and $\mathrm{Ni}$ in the water phase and $\mathrm{Na}$ in the hydroxylamine phase, the percentage of each element leached from the whole sample was less than $10 \%$ (majority are also less than $5 \%$ ) of the composite concentration. For water phase, the mean leaching of the major elements such as $\mathrm{Ca}(13.01-1105.91 \mathrm{mg} / \mathrm{kg})$, $\mathrm{Mg}(0.49-259.13 \mathrm{mg} / \mathrm{kg}), \mathrm{K}(21.15-108.5 \mathrm{mg} / \mathrm{kg}), \mathrm{Na}$ (0.006-27.44 mg/kg), Mn (0.003-133.77 mg/kg), and Fe $(0.017-1238.84 \mathrm{mg} / \mathrm{kg})$ were $370.39,77.02,5.76,53.28$, 15.40 , and $255.09 \mathrm{mg} / \mathrm{kg}$, respectively. Trace elements $\mathrm{Pb}(0.25 \mathrm{mg} / \mathrm{kg}), \mathrm{Cu}(2.15 \mathrm{mg} / \mathrm{kg})$, As $(0.59 \mathrm{mg} / \mathrm{kg}), \mathrm{Zn}$ (13.52 mg/kg), Co (3.22 mg/kg), and Ni (10.87 mg/kg) were leached out to a considerable amount in the water phase (WF). The percentages leached for $\mathrm{Ca}, \mathrm{Mg}, \mathrm{K}, \mathrm{Na}$, $\mathrm{Mn}, \mathrm{Fe}, \mathrm{Pb}, \mathrm{Cu}, \mathrm{As}, \mathrm{Zn}, \mathrm{Co}$, and $\mathrm{Ni}$ were $9.78 \%, 3.19 \%$, $1.89 \%, 0.86 \%, 3.31 \%, 1.20 \%, 0.5 \%, 4.19 \%, 10.46 \%$, $8.46 \%$ and $10.89 \%$, respectively. For the ammonium acetate leach (AMF), the average sample concentration for $\mathrm{Ca}(34.61-1280.83 \mathrm{mg} / \mathrm{kg}), \mathrm{Mg}(9.21-96.67 \mathrm{mg} / \mathrm{kg}$ ), 


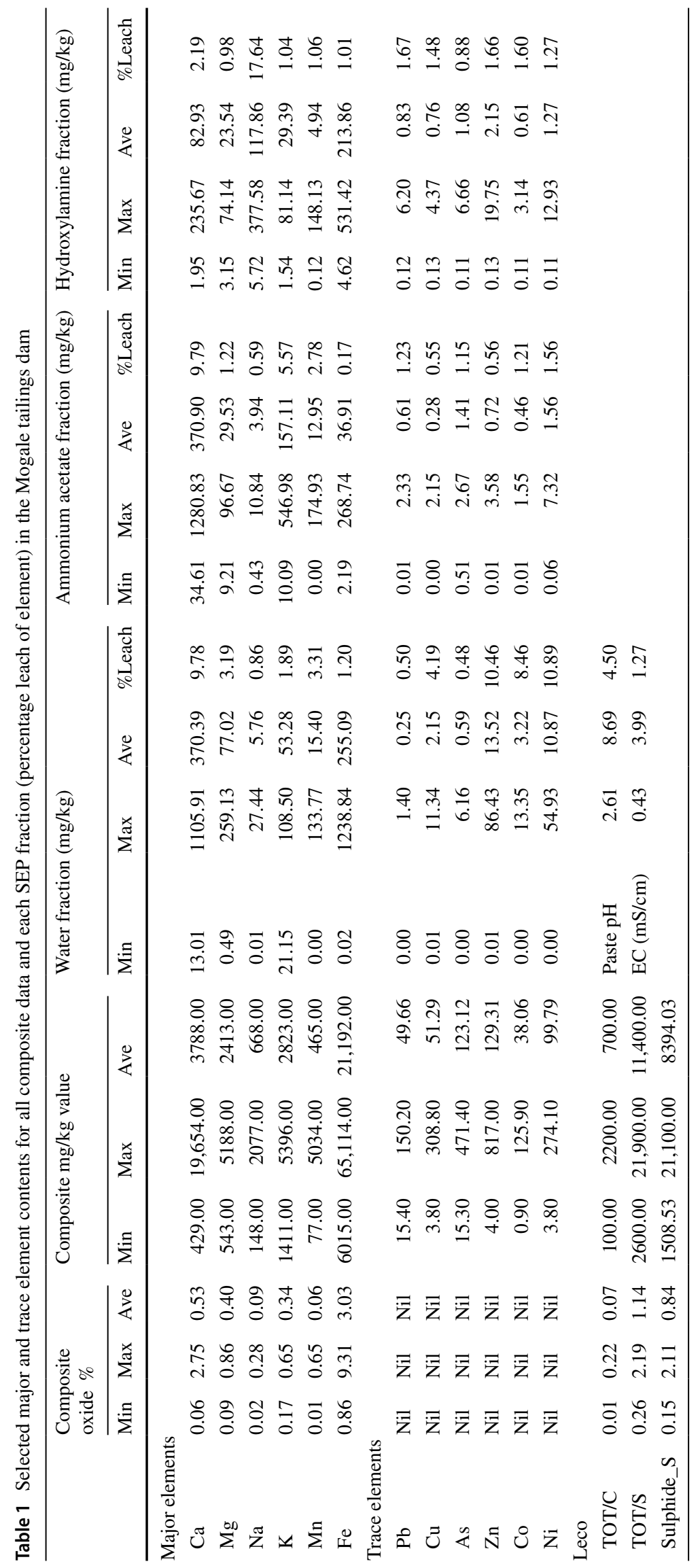


$\mathrm{Na}(0.43-10.84 \mathrm{mg} / \mathrm{kg}), \mathrm{K}(10.09-546.98 \mathrm{mg} / \mathrm{kg}), \mathrm{Mn}$ $(0.004-174.93 \mathrm{mg} / \mathrm{kg})$, and $\mathrm{Fe}(2.19-268.74 \mathrm{mg} / \mathrm{kg})$ were $370.9 \mathrm{mg} / \mathrm{kg}, 29.53 \mathrm{mg} / \mathrm{kg}, 3.94 \mathrm{mg} / \mathrm{kg}, 157.11 \mathrm{mg} / \mathrm{kg}$, $12.95 \mathrm{mg} / \mathrm{kg}$, and $36.91 \mathrm{mg} / \mathrm{kg}$. For the hydroxylamine leach (HF), Ca (1.95-235.67 mg/kg), Mg (3.15-74.14 mg/ $\mathrm{kg}), \mathrm{Na}(5.72-377.58 \mathrm{mg} / \mathrm{kg}), \mathrm{K}(1.54-81.14 \mathrm{mg} / \mathrm{kg}), \mathrm{Mn}$ $(0.12-148.13 \mathrm{mg} / \mathrm{kg})$, and Fe $(4.62-531.42 \mathrm{mg} / \mathrm{kg})$ average concentrations were 82.93, 23.54, 117.86, 29.39, 4.94, and $213.86 \mathrm{mg} / \mathrm{kg}$, respectively. The water leach (WF) showed the highest leaching values for most elements compared to other leachants. Trace elements such as $\mathrm{Pb}(0.61 \mathrm{mg} /$ $\mathrm{kg}), \mathrm{Cu}(0.28 \mathrm{mg} / \mathrm{kg}), \mathrm{As}(1.41 \mathrm{mg} / \mathrm{kg}), \mathrm{Zn}(0.72 \mathrm{mg} / \mathrm{kg})$, Co $(0.46 \mathrm{mg} / \mathrm{kg})$, and $\mathrm{Ni}(1.56 \mathrm{mg} / \mathrm{kg})$ were leached out in the AMF, while in the $\mathrm{HF} \mathrm{Pb}(0.83 \mathrm{mg} / \mathrm{kg}), \mathrm{Cu}(0.76 \mathrm{mg} /$ $\mathrm{kg})$, As (1.08 mg/kg), Zn (2.15 mg/kg), Co $(0.61 \mathrm{mg} / \mathrm{kg})$, and $\mathrm{Ni}(1.27 \mathrm{mg} / \mathrm{kg})$ were also leached out. The average total sulphur of the composite samples $(11,400 \mathrm{mg} / \mathrm{kg})$ was greater than the sulphide-sulphur $(8394.03 \mathrm{mg} / \mathrm{kg})$ present, indicating that the tailings had a considerable amount of oxidizable sulphide. The average total carbon was $700 \mathrm{mg} /$ $\mathrm{kg}$. The average $\mathrm{pH}$ of 4.5 showed that the mine tailings were generally acidic. An average EC value of $1.27 \mathrm{mS} /$ $\mathrm{cm}$ showed a considerable presence of leachable elements (Abegunde et al. 2016).

\section{Mineralogical and textural description of the tailings}

As described in a study performed by Abegunde et al. (2016), the morphology of a few randomly selected tailing samples were studied using SEM-EDS based on the specific horizons in the cores as displayed in Fig. 3. The SEM image measured at $25 \mu \mathrm{m}$ shows non-spherical shapes of varying particle sizes. Sample MT020 (1 m depth) showed inhomogeneity that did not distinguish the grains properly. The high presence of $\mathrm{Si}, \mathrm{Al}$, and low $\mathrm{S}$ in EDS indicated possible oxidised zones. The EDS result for Sample MT005 (5 m depth) showed a flake-like shape with sharp edges with high values of $\mathrm{Si}, \mathrm{S}$, and $\mathrm{Fe}$, yet demonstrated low $\mathrm{Al}$ levels compared to MT001 that indicated a more enrich zone, which was altered and contained some sulphides. Sample MT007 (about $7.8 \mathrm{~m}$ in depth) showed smaller round shapes, flake-like shapes, and bigger particles. A low $\mathrm{Si}$, but high $\mathrm{Fe}$ and $\mathrm{S}$ content in this sample compared to others indicated the presence of Fe mineral, associated with sulphides. For sample MT025 (6 $\mathrm{m}$ depth), the image is characterised by varying particle shapes that show high Fe and other elements. Additionally, more elements were identified in the EDS analysis. In general, the EDS analysis showed inhomogeneous distribution of particles and metals for all samples.

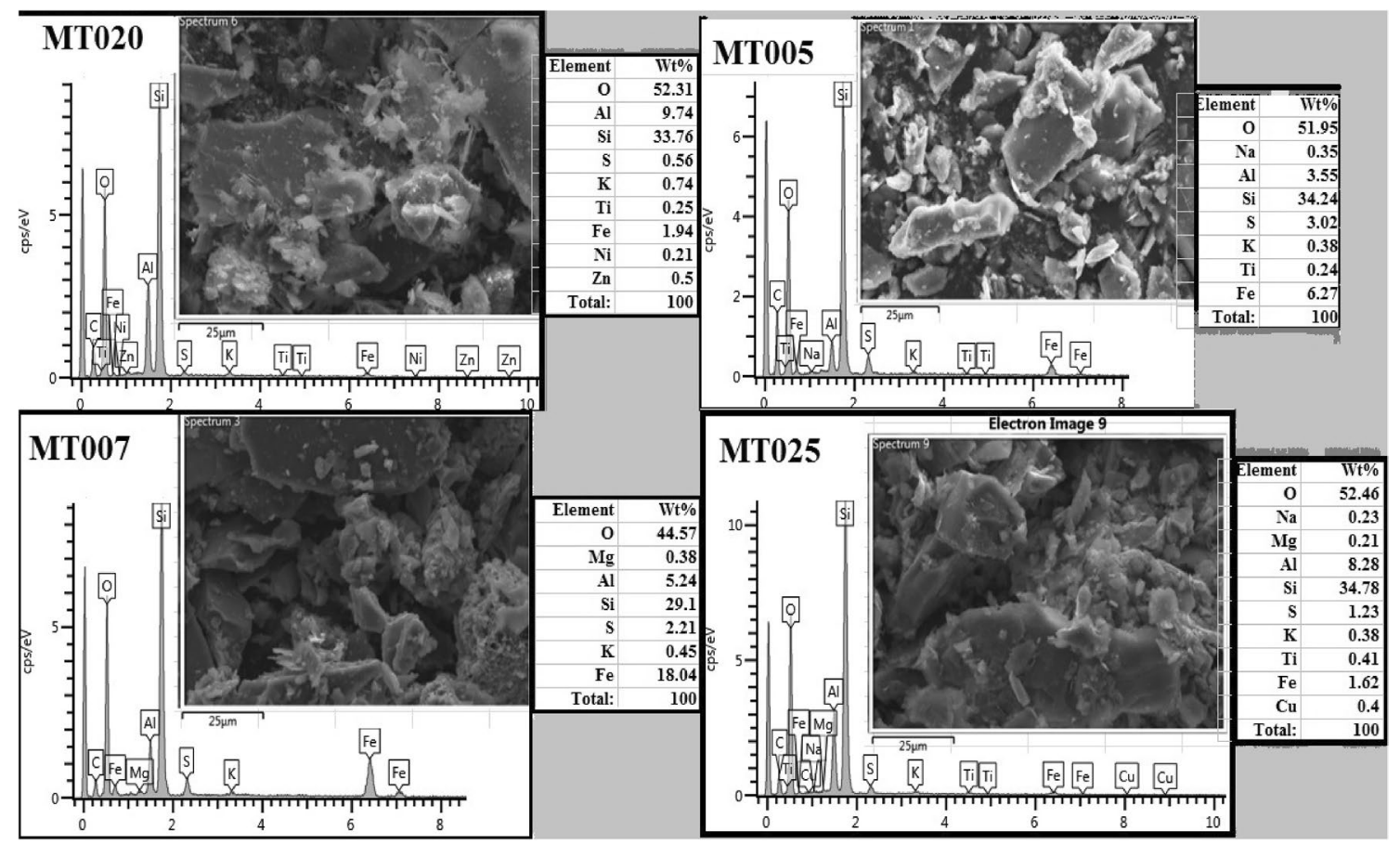

Fig. 3 SEM-EDX analysis of selected samples representing peculiar horizon within the Mogale tailings dam 


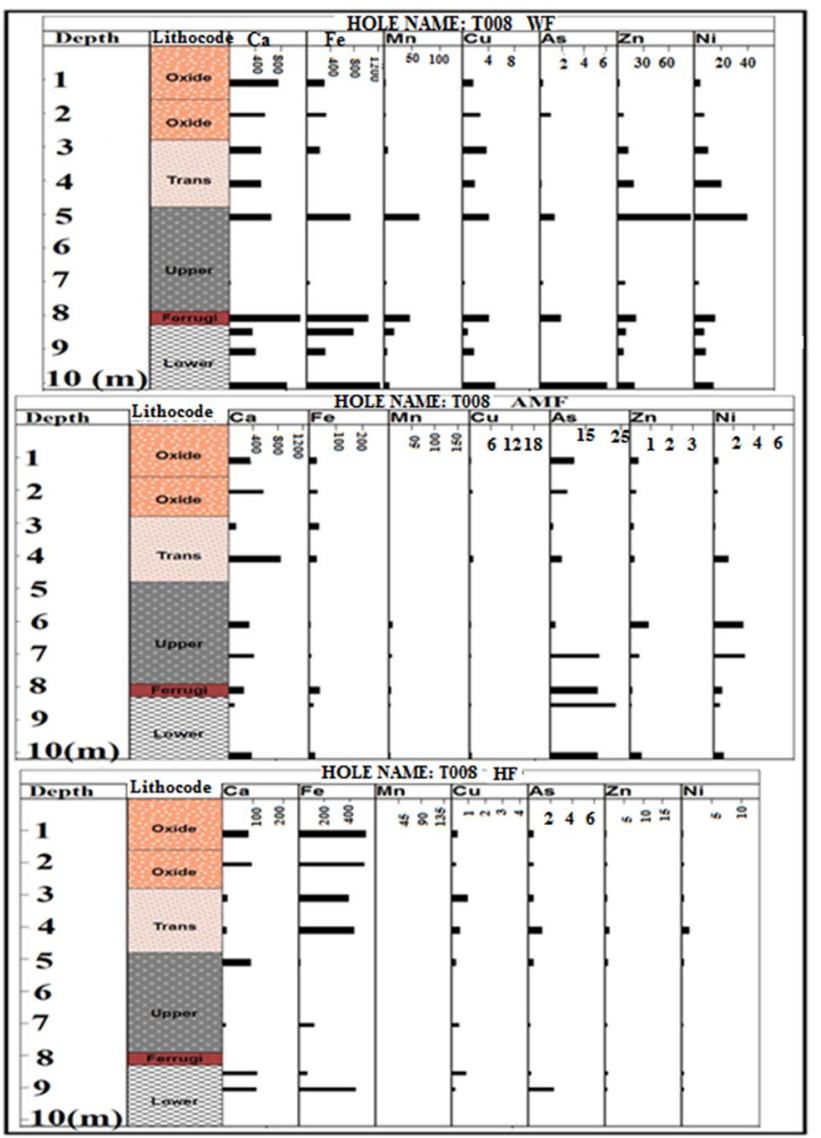

Fig. 4 Downhole plots of selected elements from each SEP fraction in borehole T008. $W F$ water fraction, $A M F$ ammonium acetate fraction, $H F$ hydroxylamine fraction

\section{Downhole description of the SEP results}

Samples from boreholes T008 and T009 were further analysed by using SEP coupled with statistical analysis as presented in Fig. 4 and 5. All the values in Figs. 4 and 5 are presented in $\mathrm{mg} / \mathrm{kg}$. Generally, the water leach showed that more trace elements such as $\mathrm{Zn}, \mathrm{Cu}, \mathrm{As}$, and $\mathrm{Ni}$ were leached out by water compared to the other leachants showing their high solubility and mobility. For the major elements ( $\mathrm{Fe}, \mathrm{Ca}$, and $\mathrm{Mn}$ ), the concentration leached out in the water-leach phase increased downhole. This could be due to the available leachable material and initial elemental concentration of the tailings, which increases downhole. However, a considerable amount of calcium was leached out in the water phase. This could be attributed to the presence of secondary minerals, which are the product of redox reduction derived from the oxidation and weathering of overlaying layers.

Further observations deduced showed that a general increase in leached content downhole was observed in the water phase, while more $\mathrm{Ca}$ was released in the ammonium acetate leachant compared to other phase(s).

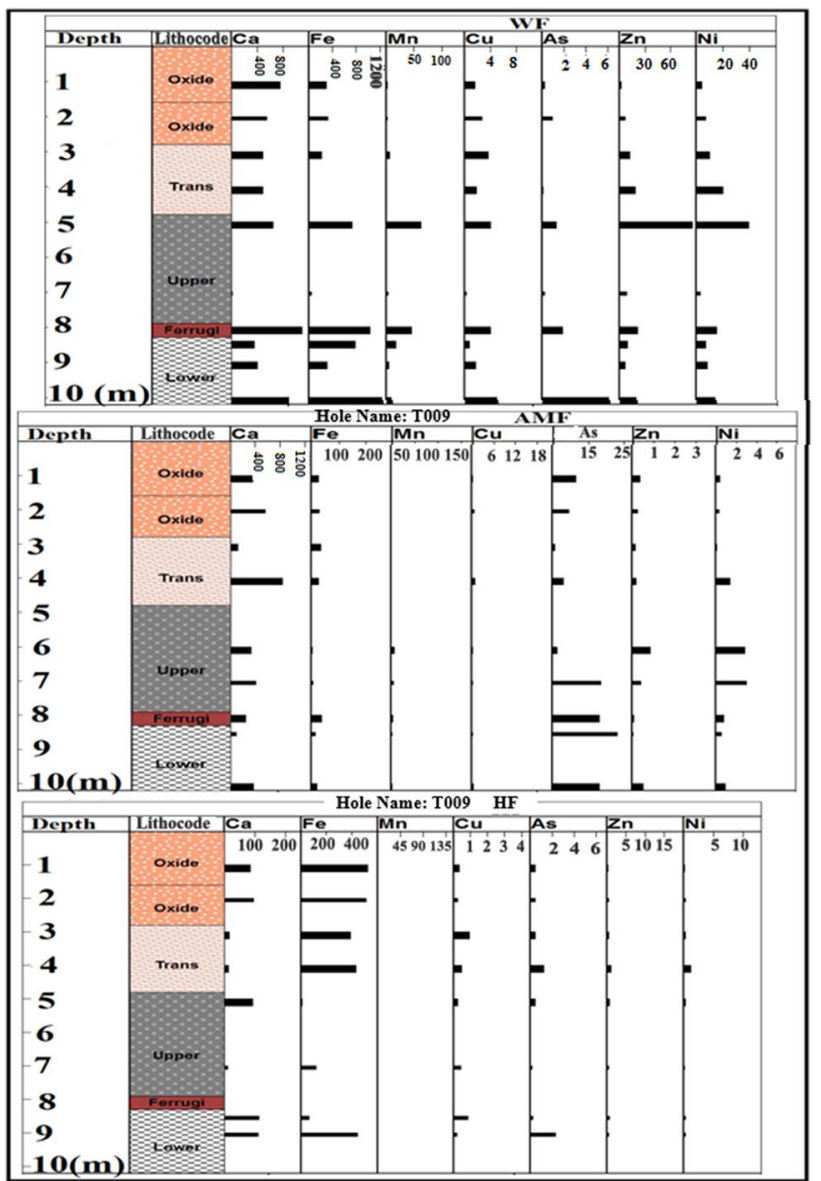

Fig. 5 Downhole plots of selected elements from each SEP fraction in borehole T009

For T008, the concentration of $\mathrm{Ca}$ increased downhole, but was more prominent at the base of the upper zone, whereas for T009 it increased downhole and later decreased by demonstrating uneven weathering. The presence of high $\mathrm{Ca}$ in AMF indicated the presence of carbonate materials or neutralising minerals. No specific trend was observed for other major elements, except for a very low amount leached out in all sample concentrations of Mn from T009 compared to borehole T008. For the trace elements $(\mathrm{Cu}, \mathrm{Zn}, \mathrm{As}$, and $\mathrm{Ni}$ ), there was no particular trend downhole, although the topmost layer showed low concentrations indicating extreme download. Among the toxic trace elements, As leaching was most prominent from the two boreholes.

For the hydroxylamine fraction (HF), Fe was prominently leached compared to other major elements. Low values were observed for $\mathrm{Mn}$ and $\mathrm{Ca}$ in both boreholes. There is no particular downhole trend in the concentration of the trace elements as shown in Figs. 4 and 5. In borehole T009, Fe showed a high concentration between oxidised and transition zone. 


\section{Statistical analysis}

\section{Factor analysis}

Principal component analysis was used to extract factors based on varimax with the Kaiser normalisation rotation method, with eigenvalue $>1$. Values lower than \pm 0.3 were not considered because of their significance (Table 1). In the water fraction, four factors extracted are given as: factor 1 indicates positive components for $\mathrm{Ni}, \mathrm{Zn}, \mathrm{Mn}, \mathrm{Mg}, \mathrm{Pb}, \mathrm{Fe}$, and $\mathrm{K}$; factor 2 indicates positive components for $\mathrm{Mn}, \mathrm{Mg}$, As, $\mathrm{P}$ and $\mathrm{Fe}$, but negative component for $\mathrm{Na}$; factor 3 shows positive components for $\mathrm{Mg}, \mathrm{Pb}, \mathrm{Ca}, \mathrm{Fe}$ and $\mathrm{K}$, while, factor 4 indicates a positive component for $\mathrm{Cu}$.

Based on eigenvalues greater than one, factor 1, 2, 3 and 4 represent $32.685 \%, 18.087 \%, 16.037 \%$, and $13.976 \%$ of the sample, respectively. These estimates denote the order of relevance of the four factors. Clearly, this accounts for a cumulative sum of $80.8 \%$ of the sample. Out of the four factors, Fe contributed to three factors that indicate the presence of $\mathrm{Fe}$ ions (assuming $\mathrm{Fe}^{2+}$ and $\mathrm{Fe}^{3+}$ ) responsible for the acidity increase of the tailings.

In the effect, factor 1 represents the most labile elements that can be easily leached and factor 3 shows neutralising agents such as $\mathrm{Ca}$ and $\mathrm{Mg}$ carbonates, which do not play a prominent role as $\mathrm{Fe}$, and thereby provided insufficient neutralisation potential.

In the case of the ammonium acetate fraction, three factors were identified. Based on eigenvalues greater than one, Factors 1, 2, and 3 represent $33.130 \%, 20.055 \%$, and $16.897 \%$ of the sample, respectively. These estimates denote the order of relevance of the factors. This accounts for a cumulative sum of $70.082 \%$ of the sample. Factor 1 indicates positive values for $\mathrm{Ca}, \mathrm{Mg}, \mathrm{Na}, \mathrm{Zn}, \mathrm{Ni}, \mathrm{Mn}$, and $\mathrm{Fe}$, but negative values for As; factor 2 indicates positive values for $\mathrm{Ca}, \mathrm{K}, \mathrm{Pb}$, and $\mathrm{Mn}$; and factor 3 indicates positive values for $\mathrm{Cu}$, As, and $\mathrm{Fe}$. In factor 1 , the effect of the carbonates present on the acidity was observed when $\mathrm{Ca}$ associated with Fe. This denotes that the tailings contained a considerable amount of neutralising potential. Therefore, as leaching conditions become stronger, there is a tendency for an increase in alkalinity within the tailings.

For the hydroxylamine phase, there were a greater number of factors of more complexity. In this case, only five factors were identified. Based on eigenvalues greater than 1 , factors $1,2,3,4$, and 5 represent $38.788 \%, 14.620 \%$, $10.542 \%, 8.794 \%$, and $8.475 \%$ of the sample, respectively. More so, factor 1 indicates positive values for $\mathrm{Ni}, \mathrm{Zn}, \mathrm{Pb}$, $\mathrm{Cu}, \mathrm{Mg}, \mathrm{Fe}$, and $\mathrm{Mn}$; factor 2 indicates positive values for $\mathrm{As}$ and $\mathrm{Fe}$; factor 3 indicates positive values for $\mathrm{Ca}$ and $\mathrm{Mg}$, followed by factor 4 with a positive value for $\mathrm{K}$ and a negative value for $\mathrm{Fe}$; and lastly, factor 5 showed a positive value for $\mathrm{Na}$ and a negative value for $\mathrm{Mn}$. This means that most trace elements such as $\mathrm{Ni}, \mathrm{Zn}, \mathrm{Pb}$, and $\mathrm{Cu}$ are associated with the $\mathrm{Fe} / \mathrm{Mn}$ oxides, and easily transported with the acidgenerating ions.

\section{Acid generation potential}

Acid base accounting (ABA) on various Witwatersrand gold tailings samples showed AP:NP ratios from 1:0.5 to 1:2.78 (Bezuidenhout and Rousseau 2006). Measured S concentrations varied between $0.17 \%$ and $0.45 \% \mathrm{~S}$, thus placing the tailings within the uncertain range, in terms of its potential to generate AMD (Bezuidenhout and Rousseau 2006). However, AMD generation is really a complex encompassing chemical, biological, and electrochemical reactions affected by fluctuating environmental conditions, in which pyrite and marcasite remain the predominant acid producers (Simate and Ndlovu 2014). Despite the fact that weathered tailings samples indicated a lower average of $\% \mathrm{~S}(1.21 \%)$ as compared to the fresh tailings (2.60\%), the acid neutralisation potential of the weathered samples was higher than that of the fresh samples. From the geochemical data, the total $\% \mathrm{~S}$ for these samples ranged from 0.26 to $2.75 \%$ (Abegunde et al. 2016) in all samples. However, from the analysis of total percentage of sulphide-sulphur, the available oxidizable sulphide ranges from 0.15 to $2.11 \%$ of selected borehole samples (see Table 1). A prominent association between $\mathrm{Ca}$ and $\mathrm{Mg}$ (as established by factor analysis) indicated that they both contribute to the neutralising potential of the tailings, and the use of $\mathrm{Mg}$ in calculating cumulative net acid producing potential (NAPP) is justified. From Eqs. 1 to 3, the net acid producing potential is calculated separately as NAPP and cumulative NAPP. This is calculated as NP/MPA and cumulative NP/MPA, respectively, and the results are displayed in Table 2.

If NAPP or C. NAPP is less than one, then it indicates that mine tailings are acid generating. Otherwise, if these values are greater than one, it indicates that the mine tailings have the potential to be acidic. Likewise, if these values are greater than two, this means that the mine tailings are not acid generating. From Table 2, the NAPP (NP/MPA) for total sulphur is less than one for all samples. Literally, this means that the mine tailing is acid generating at all layers. Most samples that fall within layer 1 have values greater than 0.5 , while other samples indicate low value of NAPP. The NAPPs (NP/MPAs) for total sulphide-sulphur is less than one for all samples, except for MT038 and MT010 samples from the top most layers.

Also, in Table 3, samples at the top layer indicate values greater than 0.5 for NAPPs. This indicates that the mine tailings considerably contain high acidity-generating potential despite the presence of neutralisation materials. 
Table 2 Factor analysis result for all SEP fractions (extraction method: principal component analysis. Rotation method: varimax with Kaiser normalisation

\begin{tabular}{|c|c|c|c|c|c|c|c|c|c|c|c|c|c|c|}
\hline \multicolumn{5}{|c|}{ Rotated component matrix ${ }^{\mathrm{a}}(\mathrm{WF})$} & \multicolumn{4}{|c|}{ Rotated component matrix ${ }^{a}$ AM-F } & \multicolumn{6}{|c|}{ Rotated component matrix ${ }^{\mathrm{a}} \mathrm{HH}-\mathrm{F}$} \\
\hline & \multicolumn{4}{|c|}{ Component } & & \multicolumn{3}{|c|}{ Component } & & \multicolumn{5}{|c|}{ Component } \\
\hline & 1 & 2 & 3 & 4 & & 1 & 2 & 3 & & 1 & 2 & 3 & 4 & 5 \\
\hline $\mathrm{Ni}$ & $\mathbf{0 . 9 3 1}$ & & & & $\mathrm{Ca}$ & 0.61 & 0.618 & & $\mathrm{Ni}$ & 0.976 & & & & \\
\hline $\mathrm{Zn}$ & 0.929 & & & & $\mathrm{Mg}$ & 0.797 & & & $\mathrm{Zn}$ & 0.951 & & & & \\
\hline $\mathrm{Mn}$ & 0.691 & 0.55 & & & $\mathrm{Na}$ & 0.756 & & & $\mathrm{~Pb}$ & 0.946 & & & & \\
\hline $\mathrm{Mg}$ & 0.668 & 0.341 & 0.437 & & $\mathrm{~K}$ & & 0.904 & & $\mathrm{Cu}$ & 0.925 & & & & \\
\hline $\mathrm{Pb}$ & 0.53 & & 0.525 & & $\mathrm{~Pb}$ & & 0.732 & & As & & 0.914 & & & \\
\hline As & & 0.804 & $\mathbf{0 . 3 3 7}$ & & $\mathrm{Cu}$ & & , & 0.85 & $\mathrm{Ca}$ & & & 0.908 & & \\
\hline $\mathrm{Fe}$ & 0.469 & 0.7 & 0.394 & & As & -0.472 & & 0.69 & $\mathrm{Mg}$ & 0.517 & & 0.587 & & \\
\hline $\mathrm{Na}$ & & -0.543 & & & $\mathrm{Zn}$ & 0.835 & & & $\mathrm{~K}$ & & & & 0.878 & \\
\hline $\mathrm{Ca}$ & & & 0.884 & & $\mathrm{Ni}$ & 0.814 & & & $\mathrm{Fe}$ & 0.357 & 0.353 & & -0.502 & \\
\hline $\mathrm{K}$ & 0.405 & & 0.772 & & $\mathrm{Mn}$ & 0.581 & 0.581 & & $\mathrm{Na}$ & & & & & 0.813 \\
\hline $\mathrm{Cu}$ & & & & 0.957 & $\mathrm{Fe}$ & 0.304 & & 0.659 & $\mathrm{Mn}$ & 0.363 & & & & -0.61 \\
\hline
\end{tabular}

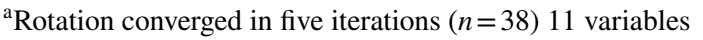

For the cumulative NAPP, all core samples were less than one except for MT001, MT002, MT018-1 and MT038, which were greater than one but less than two. In this case, all other samples were topmost layers except for MT018-1. Moreover, the values for C. NAPP imply that if both $\mathrm{CaO}$ and $\mathrm{MgO}$ were present in the tailings as a buffer, they could only neutralise AMD generated in the top layer 1. This shows that the tailings contained sulphides and insufficient buffering minerals, which made it susceptible to acid generation, because the finely ground material had a large accessible reactive surface area. Neutralisation potential evaluation with mineralogical assessment is not largely used, since it is challenging to accurately estimate the sample mineralogy (Bouzahzah et al. 2014) using qualitative XRD analysis.

However, most trace elements were released due to acidity. After the alkalinity of the tailing increased, more $\mathrm{Fe}$ oxides were released that produced more $\mathrm{H}+$ ions. This reduced the alkalinity. But as the acidity increased, several toxic metals were released.

\section{Relationship between leachates and acid generation potential}

The statistical deductions attained established that $\mathrm{pH}$ or acidity, $\mathrm{Fe}$ ions, $\mathrm{Ca}^{+}$, and $\mathrm{Mg}^{2+}$ played a major role in the released metals. The variation in the $\mathrm{Fe}$ and $\mathrm{Ca}$ leached out in each phase indicates the presence of oxidizable sulphide and neutralising minerals. The water phase releases the bulk of the elements leached compared to other phases. Also, the water phase denotes the natural environment. If the tailings are exposed to the natural leaching agent (WF), elements such as oxidised $\mathrm{Fe}, \mathrm{Ca}$ ions and associated trace elements are released (Grover et al. 2016). This indicates that the tailings are susceptible to weathering under normal condition (Grover et al. 2016). More Fe ions released are responsible for the increased acidity that $\mathrm{Ca}$ ions generated, because it could not completely neutralise it. As the leaching environment becomes harsh (AMF) and more carbonates are released, then more $\mathrm{Ca}$ ions are released. In the end, the available $\mathrm{Fe}$ ions react to produce more acidity (HF), which leads to a greater amount of trace elements to be released. Due to this, zones of accumulation showed increased $\mathrm{pH}$ compared to the topmost and the bottommost layers. From the acid base accounting (ABA) results, the NAPP and cumulative NAPP showed that overall, the tailings would generate acidity due to the high presence of leachable sulphides. The trends observed in the carbonate phase indicated that despite the posit of acidity, the tailings contain a considerable amount of neutralising agent to serve as a buffer. However, the trend observed in the Mn and Fe phase showed that in the long run, the Fe ions released will overcome the buffer system within the tailings and more acidity will be produced and thereby release toxic metals.

From the results, the acid generation potential of the system relates to the speciation of elements. In addition, the presence of more oxidizable sulphides makes these gold tailings a threat to the environment due to the release of toxic metals.

\section{Conclusions}

In this study, the inhomogeneous characteristics of the mine tailings particles from the SEM image were revealed, while surface samples showed the presence of reactivity. However, 


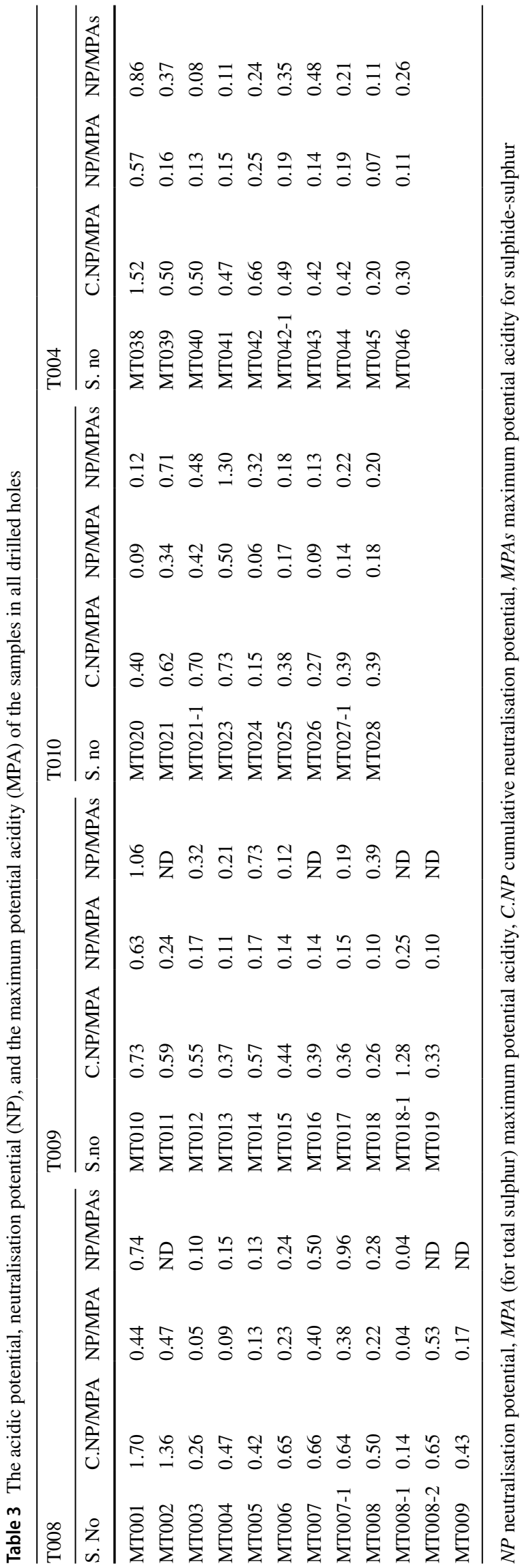

findings attained indicate that $\mathrm{pH}$ or acidity, $\mathrm{Fe}$ ions, $\mathrm{Ca}^{2+}$ and $\mathrm{Mg}^{2+}$ played a major role in the released metals. Out of the four factors identified in factor analysis results for water fraction (WF), Fe contributed to three factors that showed the presence of $\mathrm{Fe}$ ions (assuming $\mathrm{Fe}^{2+}$ and $\mathrm{Fe}^{3+}$ ) responsible for the increased acidity of the tailings. A more prominent Fe effect showed positive acidic potential despite the presence of $\mathrm{Mg}$ and $\mathrm{Ca}$. For the water phase, the release of $\mathrm{Fe}$ ions into the surroundings can be associated with the gradual mobility or releases of toxic metals. Factor 1 represents the most labile elements that can be easily leached, while factor 3 represents the presence of neutralising agents such as $\mathrm{Ca}$ and $\mathrm{Mg}$ carbonates. However, this particular factor did not play a more integral role than $\mathrm{Fe}$, and thus could not provide enough neutralisation potential. For WF, Fe has values for ocomponent 1, 2, 3 indicating that the presence of $\mathrm{Fe}$ assist in the release of most elements. Ni (0.931), Zn (0.929), $\mathrm{As}(0.804), \mathrm{Ca}(0.844)$ and $\mathrm{Cu}(0.957)$ show high positive values indicating that they are highly susceptible to water leach. Only $\mathrm{Cu}(0.957)$ has no association with $\mathrm{Fe}$, indicating that it is leached non $\mathrm{Fe}$-containing minerals.

In the case of the ammonium acetate fraction (AMF), findings indicated that $\mathrm{Ca}(0.61) \& \mathrm{Mg}(0.797)$ are was associated with Fe. This demonstrates the effect of the carbonates found on the acidity, and the tailings contain a considerable amount of neutralising potential. Therefore, as the leaching conditions become stronger, there is a tendency for an increase in alkalinity within the tailings and the carbonate minerals play a major role in releasing more buffer. Further findings showed that the positive value of Fe reflected the potential release of $\mathrm{Fe}$ ionic species into the environment, which can increase the acidity of the tailings. Most trace elements, such as $\mathrm{Ni}, \mathrm{Zn}, \mathrm{Pb}$, and $\mathrm{Cu}$ with values $>0.9$, are associated with the Fe/Mn oxides phase leachable. Thus, easily transport with the acid-generating ions. Potentially, more carbonates are released with more $\mathrm{Ca}$ ions as the leaching environment harsh (AMF). Eventually, the available Fe ions react to produce more acidity (HF), which caused a greater amount of trace elements to be released. That is why zones of accumulation showed increased $\mathrm{pH}$ compared to the topmost and the bottommost layers. The trends observed in the carbonate phase showed that, despite the posit of acidity, the tailings contain a considerable amount of neutralising agent to serve as a buffer. The trend observed in the $\mathrm{Mn}$ and Fe phase showed that in the long run, the Fe ions released will overcome the buffer system within the tailings and more acidity will be produced, thereby releasing toxic metals.

Generally, the NAPP and cumulative NAPP showed that overall, the tailings would generate acidity due to the high presence of leachable sulphides. The use of sulphur-sulphide as compared to total sulphur in calculating neutralisation potential help to avoid considerable assumption in estimating amount of acid produced. 


\section{References}

Abegunde OA, Okujeni C, Wu C, Siad A (2016) Distribution patterns of contaminants in the Mogale Gold tailing dam: a case study from South Africa. Environ Earth Sci 75(20):1365

Abollino O, Malandrino M, Giacomino A, Mentasti E (2011) The role of chemometrics in single and sequential extraction assays: a review: part I. Extraction procedures, uni-and bivariate techniques and multivariate variable reduction techniques for pattern recognition. Anal Chim Acta 688(2):104-121

Abzalov M (2008) Quality control of assay data: a review of procedures for measuring and monitoring precision and accuracy. Explor Mini Geol 17:131-144

Alkarkhi AF, Ismail N, Ahmed A, Mat Easa A (2009) Analysis of heavy metal concentrations in sediments of selected estuaries of Malaysia-a statistical assessment. Environ Monit Assess 153(1-4):179-185

Bezuidenhout N, Rousseau PD (2006) Investigations into the depth and rate of weathering on Witwatersrand gold tailings dam surfaces as key information for long-term ARD risk assessments. In: 7th international conference on acid rock drainage (ICARD), The American Society of Mining and Reclamation (ASMR), pp 128-139

Bouzahzah H, Benzaazoua M, Bussiere B, Plante B (2014) Prediction of acid mine drainage: importance of mineralogy and the test protocols for static and kinetic tests. Mine Water Environ 33(1):54-65

Cukrowska EM, Govender K, Viljoen M (2004) Ion mobility based on column leaching of South African gold tailings dam with chemometric evaluation. Chemosphere 56(1):39-50

EPA (2015) MARLAP Manual Volume II: Chapter 12, Laboratory Sample Preparation https://www.epa.gov/sites/production/files /2015-05/documents/402-b-04-001b-12-final.pdf

Eze CP, Nyale SM, Akinyeye RO, Gitari WM, Akinyemi SA, Fatoba OO, Petrik LF (2013) Chemical, mineralogical and morphological changes in weathered coal fly ash: a case study of a brine impacted wet ash dump. J Environ Manag 129:479-492

Favas PJ, Pratas J, Gomes MEP, Cala V (2011) Selective chemical extraction of heavy metals in tailings and soils contaminated by mining activity: environmental implications. J Geochem Explor 111(3):160-171

Gautama RS, Kusuma GJ (2008) Evaluation of geochemical tests in predicting acid mine drainage potential in coal surface mine. Mine Water Environ 2008:271-274

Gleyzes C, Tellier S, Astruc M (2002) Fractionation studies of trace elements in contaminated soils and sediments: a review of sequential extraction procedures. TrAC Trends Anal Chem 21(6-7):451-467

Grover BPC, Johnson RH, Tutu H (2016) Leachability of metals from gold tailings by rainwater: an experimental and geochemical modelling approach. Water SA 42(1):38-42

Jamieson HE, Walker SR, Parsons MB (2015) Mineralogical characterization of mine waste. Appl Geochem 57:85-105

Lawrence RW, Scheske M (1997) A method to calculate the neutralization potential of mining wastes. Environ Geol 32(2):100-106

Loska K, Wiechuła D (2003) Application of principal component analysis for the estimation of source of heavy metal contamination in surface sediments from the Rybnik Reservoir. Chemosphere 51(8):723-733

Martin JM, Nirel P, Thomas AJ (1987) Sequential extraction techniques: promises and problems. Mar Chem 22(2-4):313-341

McCarthy T, Rubidge B (2005) The story of earth and life a Southern African perspective on a 4.6-billion year journey. Struik, Cape Town, p 333
Mil-Homens M, Costa AM, Fonseca S, Trancoso MA, Lopes C, Serrano $\mathrm{R}$, Sousa R (2013) Characterization of heavy-metal contamination in surface sediments of the Minho River Estuary by way of factor analysis. Arch Environ Contam Toxicol 64(4):617-631

Naicker K, Cukrowska E, McCarthy T (2003) Acid mine drainage arising from gold mining activity in Johannesburg, South Africa and environs. Environ Pollut 122(1):29-40

Nengovhela A, Yibas B, Ogola J (2007) Characterisation of gold tailings dams of the Witwatersrand Basin with reference to their acid mine drainage potential, Johannesburg, South Africa, Water SA. https://doi.org/10.4314/wsa.v32i4.5290

Oh C, Ji S, Chon C, Yim G, Cheong Y (2017) Reliability improvement for predicting acid-forming potential of rock samples using static tests. Environ Monit Assess 189(5):207

Paktunc AD (1999) Characterization of mine wastes for prediction of acid mine drainage. In: Environmental impacts of mining activities. Springer, Berlin, pp 19-40

Parbhakar-Fox A, Lottermoser BG (2015) A critical review of acid rock drainage prediction methods and practices. Miner Eng $82: 107-124$

Piercey SJ (2014) Modern analytical facilities 2. A review of quality assurance and quality control (QA/QC) procedures for lithogeochemical data. Geoscience Canada, pp 75-88

Price W (2009) Prediction manual for drainage chemistry from sulphidic geological materials. MEND Report 1.20. 1. Natural Resources Canada

Price WA, Morin K, Hutt N (1997) Guidelines for the prediction of acid rock drainage and metal leaching for mines in British Columbia: Part II. Recommended procedures for static and kinetic testing. In: Proceedings of the Fourth International Conference on Acid Rock Drainage, vol. 1, pp 15-30

Schneiderhan EA (2008) Neoarchaean clastic rocks on the Kaapvaal Craton: provenance analyses and geotectonic implications. Doctoral dissertation, University of Johannesburg

Simate GS, Ndlovu S (2014) Acid mine drainage: challenges and opportunities. J Environ Chem Eng 2(3):1785-1803

Skousen J (2017) A methodology for geologic testing for land disturbance: acid-base accounting for surface mines. Geoderma 308:302-311

Skousen J, Simmons J, McDonald LM, Ziemkiewicz P (2002) Acidbase accounting to predict post-mining drainage quality on surface mines. J Environ Qual 31(6):2034-2044

Slavković L, Škrbić B, Miljević N, Onjia A (2004) Principal component analysis of trace elements in industrial soils. Environ Chem Lett 2(2):105-108

Tutu H, McCarthy T, Cukrowska E (2008) The chemical characteristics of acid mine drainage with particular reference to sources, distribution and remediation: the Witwatersrand Basin, South Africa as a case study. Appl Geochem 23(12):3666-3684

Viljoen MJ, Reimold WU (2002) An introduction to South Africa's geological heritage. Mintek in association with the Geological Society of South Africa, Randburg

Yong RN, Galvez-Cloutier R, Phadungchewit Y (1993) Selective sequential extraction analysis of heavy-metal retention in soil. Can Geotech J 30(5):834-847

Publisher's Note Springer Nature remains neutral with regard to jurisdictional claims in published maps and institutional affiliations. 